\title{
Front Matter: Volume 11649
}

, "Front Matter: Volume 11649," Proc. SPIE 11649, Three-Dimensional and Multidimensional Microscopy: Image Acquisition and Processing XXVIII, 1164901 (9 April 2021); doi: 10.1117/12.2596573

SPIE. Event: SPIE BiOS, 2021, Online Only 


\title{
PROGRESS IN BIOMEDICAL OPTICS AND IMAGING

\section{Three-Dimensional and Multidimensional Microscopy: Image Acquisition and Processing XXVIII}

\author{
Thomas G. Brown \\ Tony Wilson \\ Laura Waller \\ Editors \\ 6-11 March 2021 \\ Online Only, United States \\ Sponsored and Published by \\ SPIE
}


The papers in this volume were part of the technical conference cited on the cover and title page. Papers were selected and subject to review by the editors and conference program committee. Some conference presentations may not be available for publication. Additional papers and presentation recordings may be available online in the SPIE Digital Library at SPIEDigitalLibrary.org.

The papers reflect the work and thoughts of the authors and are published herein as submitted. The publisher is not responsible for the validity of the information or for any outcomes resulting from reliance thereon.

Please use the following format to cite material from these proceedings:

Author(s), "Title of Paper," in Three-Dimensional and Multidimensional Microscopy: Image Acquisition and Processing XXVIII, edited by Thomas G. Brown, Tony Wilson, Laura Waller, Proceedings of SPIE Vol. 11649 (SPIE, Bellingham, WA, 2021) Seven-digit Article CID Number.

ISSN: 1605-7422

ISSN: 2410-9045 (electronic)

ISBN: 9781510641334

ISBN: 9781510641341 (electronic)

Published by

SPIE

P.O. Box 10, Bellingham, Washington 98227-0010 USA

Telephone +1 3606763290 (Pacific Time) · Fax +1 3606471445

SPIE.org

Copyright (c) 2021, Society of Photo-Optical Instrumentation Engineers.

Copying of material in this book for internal or personal use, or for the internal or personal use of specific clients, beyond the fair use provisions granted by the U.S. Copyright Law is authorized by SPIE subject to payment of copying fees. The Transactional Reporting Service base fee for this volume is $\$ 21.00$ per article (or portion thereof), which should be paid directly to the Copyright Clearance Center (CCC), 222 Rosewood Drive, Danvers, MA 01923. Payment may also be made electronically through CCC Online at copyright.com. Other copying for republication, resale, advertising or promotion, or any form of systematic or multiple reproduction of any material in this book is prohibited except with permission in writing from the publisher. The CCC fee code is 1605$7422 / 21 / \$ 21.00$.

Printed in the United States of America by Curran Associates, Inc., under license from SPIE.

Publication of record for individual papers is online in the SPIE Digital Library.

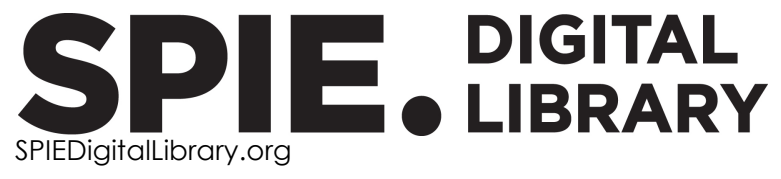

Paper Numbering: Proceedings of SPIE follow an e-First publication model. A unique citation identifier (CID) number is assigned to each article at the time of publication. Utilization of CIDs allows articles to be fully citable as soon as they are published online, and connects the same identifier to all online and print versions of the publication. SPIE uses a seven-digit CID article numbering system structured as follows:

- The first five digits correspond to the SPIE volume number.

- The last two digits indicate publication order within the volume using a Base 36 numbering system employing both numerals and letters. These two-number sets start with 00, 01, 02, 03, 04, $05,06,07,08,09,0 A, 0 B \ldots$ OZ, followed by 10-1Z, 20-2Z, etc. The CID Number appears on each page of the manuscript. 


\section{Contents}

MULTIDIMENSIONAL FLUORESCENCE IMAGING

1164904 Hyperspectral imaging approaches to characterize the distribution and expression of FRET in tissues isolated from a novel transgenic rat expressing a FRET-based probe [11649-21]

1164905 Time-resolved multi-spectral wide-field fluorescence lifetime imaging microscopy with a SPAD array detector [11649-22]

SUPER-RESOLUTION MICROSCOPY

11649 OA Sparsity-based approach for 3D super-resolution microscopy from correlation information of high emitter-density frames [1 1649-36]

IMAGE FORMATION AND ANALYSIS I

$11649 \mathrm{OB} \quad$ Quantitative phase imaging-based machine learning approaches for the analysis of adherent and suspended cells [11649-5]

IMAGE ANALYSIS AND DEEP LEARNING

11649 ol Automatic nuclei segmentation based on fuzzy C-Mean [1 1649-4]

INNOVATIONS IN OPTICAL DESIGN

11649 OM Evaluation of different illumination designs for tunable 3D structured illumination microscopy through model-based restoration [11649-15]

11649 ON High-throughput 3D imaging with compressive lens-free tomography [1 1649-16]

\section{NEW METHODS IN ILLUMINATION}

11649 OP Intensity uniformity optimization in spatial-light-modulator-based multifocal microscope [11649-26] 
MOLECULES, PARTICLES AND ORIENTATIONAL IMAGING

$11649 \mathrm{OV}$ Method for measurement of collagen monomer orientation in fluorescence microscopy [11649-19]

IMAGE FORMATION AND ANALYSIS II

11649 0X Auto-correlation for multi-view deconvolved reconstruction in light sheet microscopy [11649-10]

QUANTITATIVE IMAGING OF BIOLOGICAL SYSTEMS

1164910 3D imaging of the vagus nerve fascicular anatomy with cryo-imaging and UV excitation [11649-31]

USER INTERFACES \& VISUALIZATION

1164915 DOF adjustment and 3D free viewpoint viewing of $Z$ stack data of fluorescent microscope using image processing [11649-39]

POSTER SESSION

1164919 Effects of tissue autofluorescence on FRET efficiency estimates [11649-43]

11649 1A Robust gaussian fitting for super-resolution microscopy with fast parameters initial estimation [11649-44]

11649 1B Deconvolution optical-resolution photoacoustic microscope for high-resolution imaging of cerebral vasculature [11649-45]

iv 